\title{
Use of medical ozone in fail back surgery syndrome: a systematic review.
}

\author{
Jose Baeza-Noci, Rosa Maria Pinto-Bonilla
}

Hospital VITHAS NISA Virgen del Consuelo

\section{Әे OPEN ACCESS}

\section{Citation}

Baeza-Noci J, Pinto-Bonilla R, Use of medical ozone in fail back surgery syndrome: a systematic review. J Ozone Ther. 2020:4(5)

doi: $10.7203 / j 03 t .4 .5 .2020 .19646$

\section{Academic Editor}

Jose Baeza-Noci,

School of Medicine, Valencia

University, SPAIN

\section{Editor}

World Federation of Ozone Therapy,

Brescia, ITALY

\section{Received}

April 20, 2019

\section{Accepted}

July 20, 2019

\section{Published}

December 15, 2020

\section{Intellectual Property}

Baeza-Noci J.

This is an open access article distributed under the terms of the Creative Commons Attribution License (CC BY 4.0), which permits unrestricted use, distribution, and reproduction in any medium, provided the original author and source are credited.

\section{Authors information}

jose.baeza@doctorbaeza.es

\section{ABSTRACT}

The safety and efficacy of ozone injections in the spine for lumbar disc herniation has been proved in two systematic reviews with one metaanalysis. Many other papers with lower evidence level were published before encouraging its use for this pathology and other degenerative spinal diseases.

Fail back surgery syndrome (FBSS) is a terrible situation with no clear treatment option presently. Some authors have dared to use ozone injections in these patients, based on its antiinflammatory action and its highly save portfolio. Due to the great disability and dramatic situation of FBSS patients, a systematic review is mandatory in order to clarify the potential role of ozone in this pathology.

\section{Key words \\ ozone therapy, fail back surgery syndrome, FBSS}

\section{Introduction.}

Fail back surgery syndrome (FBSS) is defined as "spinal lower back pain of unknown origin that persists at the same site of the original pain despite surgical interventions, or appears after the procedure."' Its incidence in patients undergoing back surgery ranges from $12^{2}$ to $40^{3}$ depending on the original surgical technique. The symptoms include persistent or recurring low back and/or leg pain. Possible organic causes of FBSS include2: epidural fibrosis; arachnoiditis; mechanical factors; inflammation-induced changes in the nerve roots; structural changes in the vertebral column; and lumbar degenerative disease. A myofascial pain syndrome (MPS), has been diagnosed in $85.7 \%$ of these patients ${ }^{1}$.

Conservative treatments, such as medication and rehabilitation, usually produce unsatisfactory results ${ }^{2}$. Retrospective studies suggest that surgical revisions tend to have lower rates of improvement than the initial procedure ${ }^{4}$. Lysis of epidural adhesions as been referred to by some authors as a possible therapeutic option ${ }^{1}$ but there is no consensus 5 . Treatment with spinal cord stimulation ${ }^{6}$ and intrathecal drug delivery ${ }^{7}$ produce good results and although their high costs, when compared with the costs related to hospital stay and re-operation or secondary surgeries, these procedures may worth their cost and provide better long-term results ${ }^{8}$. In the last three decades, the application of ozone has emerged as a potential therapeutic option for patients with FBSS. It is suggested that ozone is useful for treating low back pain (LBP) due to its analgesic and anti-inflammatory properties ${ }^{9}$. Although ozone therapy is not validated yet to treat FBSS it has proved to be safe and effective to treat lumbar disc herniation ${ }^{10,11}$; its cost is low and it is a minimally invasive procedure, which yields a new therapeutic option for the FBSS's patients

\section{Material and methods.}

We have done an evidence review on the use of medical ozone in FBSS. Firstly, 
we have done and advanced search in Web-of-Science - WOS, Pubmed and Embase databases by using the term's combination: 'ozone AND ("fail back surgery" OR FBSS OR (spine AND fibrosis) OR epidurolysis)' in the fields TITLE and ABSTRACT. After duplicates removal, we got 9 papers $12,13,14,15,16,17,18,19,20$. We read the abstract and rejected 2 papers ${ }^{13,16}$ that were out of the scope of our target and a third one that was an editorial ${ }^{19}$. Secondly, we reviewed the references in the 6 remaining publications and were able to find one more paper ${ }^{21}$ potentially useful. After a full reading of all the 7 papers, we dismissed two ${ }^{15,21}$ because they did not study FBSS as a different entity inside the group of patients with chronic LBP, not showing detailed results for this problem. The quality level of the papers was evaluated according the Scottish Intercollegiate Guidelines Network (SIGN) that provides checklists ${ }^{22}$ for different designs of studies (clinical trials, cohorts, case/control).

\section{Results.}

We compiled 2 prospective cohort studies without control group and 3 retrospective cohort studies without control group. The absence of randomized control trials makes impossible to perform a metaanalysis study.

\subsection{Quality assessment.}

The quality of the five papers was evaluated using the SIGN checklist for cohort studies (table 1).

All were suitable for review although no paper could be classified as "high quality" due to the lack of control group. The authors compared their results with the natural history of FBSS or with the published results of other treatments. Bias and limitations were better referred in the prospective studies.

The main problem was the different treatments used:

- epidurolysis + epidural ozone insufflation, used in 2 papers,

- caudal epidural ozone injection, used in 1 paper,

- intradiscal + intraforaminal ozone injection, used in 2 papers,

- paravertebral ozone injection, used in 1 paper and

- systemic indirect endovenous ozone therapy (SIEVOT), used in 1 paper. 
Table 1

\begin{tabular}{|c|c|c|c|c|c|}
\hline SIGN checklist & \multicolumn{5}{|c|}{ Author / year / country } \\
\hline Internal validity & $\begin{array}{l}\text { Barbosa } \\
\text { 2016/Brazil }\end{array}$ & $\begin{array}{l}\text { Magalhaes } \\
\text { 2013/Brazil }\end{array}$ & $\begin{array}{l}\text { Hernandez } \\
\text { 2013/Mexico }\end{array}$ & $\begin{array}{l}\text { Alexander } \\
2011 / \text { taly }\end{array}$ & $\begin{array}{l}\text { Muto } \\
\text { 2008/ltaly }\end{array}$ \\
\hline $\begin{array}{l}\text { The study addresses an appropriate and clearly } \\
\text { focused question. }\end{array}$ & YES & YES & YES & YES & YES \\
\hline $\begin{array}{l}\text { The two groups being studied are selected from } \\
\text { source populations that are comparable in all re- } \\
\text { spects other than the factor under investigation. }\end{array}$ & $\begin{array}{l}\text { NOT } \\
\text { APPLY }\end{array}$ & $\begin{array}{l}\text { NOT } \\
\text { APPLY }\end{array}$ & $\begin{array}{l}\text { NOT } \\
\text { APPLY }\end{array}$ & $\begin{array}{l}\text { NOT } \\
\text { APPLY }\end{array}$ & $\begin{array}{l}\text { NOT } \\
\text { APPLY }\end{array}$ \\
\hline $\begin{array}{l}\text { The study indicates how many of the people } \\
\text { asked to take part did so, in each of the groups } \\
\text { being studied. }\end{array}$ & $\begin{array}{l}\text { NOT } \\
\text { APPLY }\end{array}$ & $\begin{array}{l}\text { NOT } \\
\text { APPLY }\end{array}$ & $\begin{array}{l}\text { NOT } \\
\text { APPLY }\end{array}$ & $\begin{array}{l}\text { NOT } \\
\text { APPLY }\end{array}$ & $\begin{array}{l}\text { NOT } \\
\text { APPLY }\end{array}$ \\
\hline $\begin{array}{l}\text { The likelihood that some eligible subjects might } \\
\text { have the outcome at the time of enrolment is as- } \\
\text { sessed and taken into account in the analysis. }\end{array}$ & NO & NO & NO & NO & NO \\
\hline $\begin{array}{l}\text { What percentage of individuals or clusters re- } \\
\text { cruited into each arm of the study dropped out } \\
\text { before the study was completed. }\end{array}$ & $\begin{array}{l}\text { NOT } \\
\text { APPLY }\end{array}$ & $0 \%$ & $0 \%$ & $\begin{array}{l}\text { NOT } \\
\text { APPLY }\end{array}$ & $\begin{array}{l}\text { NOT } \\
\text { APPLY }\end{array}$ \\
\hline $\begin{array}{l}\text { Comparison is made between full participants } \\
\text { and those lost to follow up, by exposure status. }\end{array}$ & $\begin{array}{l}\text { NOT } \\
\text { APPLY }\end{array}$ & $\begin{array}{l}\text { NOT } \\
\text { APPLY }\end{array}$ & $\begin{array}{l}\text { NOT } \\
\text { APPLY }\end{array}$ & $\begin{array}{l}\text { NOT } \\
\text { APPLY }\end{array}$ & $\begin{array}{l}\text { NOT } \\
\text { APPLY }\end{array}$ \\
\hline The outcomes are clearly defined. & YES & YES & YES & YES & YES \\
\hline $\begin{array}{l}\text { The assessment of outcome is made blind to ex- } \\
\text { posure status. If the study is retrospective this } \\
\text { may not be applicable. }\end{array}$ & $\begin{array}{l}\text { NOT } \\
\text { APPLY }\end{array}$ & $\begin{array}{l}\text { NOT } \\
\text { APPLY }\end{array}$ & $\begin{array}{l}\text { NOT } \\
\text { APPLY }\end{array}$ & $\begin{array}{l}\text { NOT } \\
\text { APPLY }\end{array}$ & $\begin{array}{l}\text { NOT } \\
\text { APPLY }\end{array}$ \\
\hline $\begin{array}{l}\text { Where blinding was not possible, there is some } \\
\text { recognition that knowledge of exposure status } \\
\text { could have influenced the assessment of out- } \\
\text { come. }\end{array}$ & NO & YES & YES & YES & NO \\
\hline $\begin{array}{l}\text { The method of assessment of exposure is reli- } \\
\text { able. }\end{array}$ & YES & YES & YES & YES & YES \\
\hline $\begin{array}{l}\text { Evidence from other sources is used to demon- } \\
\text { strate that the method of outcome assessment is } \\
\text { valid and reliable. }\end{array}$ & YES & YES & YES & YES & YES \\
\hline $\begin{array}{l}\text { Exposure level or prognostic factor is assessed } \\
\text { more than once. }\end{array}$ & YES & YES & YES & $\begin{array}{l}\text { NOT } \\
\text { APPLY }\end{array}$ & $\begin{array}{l}\text { NOT } \\
\text { APPLY }\end{array}$ \\
\hline $\begin{array}{l}\text { The main potential confounders are identified } \\
\text { and taken into account in the design and anal- } \\
\text { ysis. }\end{array}$ & YES & YES & NO & YES & YES \\
\hline Have confidence intervals been provided? & YES & YES & YES & NO & NO \\
\hline \multicolumn{6}{|l|}{ Overall assesment of the study } \\
\hline $\begin{array}{l}\text { How well was the study done to minimise the risk } \\
\text { of bias or confounding?^ }\end{array}$ & 0 & + & + & 0 & 0 \\
\hline $\begin{array}{l}\text { Taking into account clinical considerations, your } \\
\text { evaluation of the methodology used, and the sta- } \\
\text { tistical power of the study, do you think there is } \\
\text { clear evidence of an association between expo- } \\
\text { sure and outcome? }\end{array}$ & YES & YES & YES & YES & YES \\
\hline $\begin{array}{l}\text { Are the results of this study directly applicable to } \\
\text { the patient group targeted in this guideline? }\end{array}$ & YES & YES & YES & YES & YES \\
\hline
\end{tabular}




\subsection{Reported clinical results.}

The Brazilian team from the School of Medicine of the Federal University of Sao Paulo published in $2013^{17}$ a prospective pilot experience of epidurolysis followed immediately by ozone insufflation in the pathological areas of the spine with very positive results. However, the publication from $2016^{14}$, that is retrospective did not show so much benefit. Interestingly, initial values in Visual Analogic Scale (VAS) and Owestry Dissability Index (ODI) were quite similar.

Hernandez's study showed no benefit of a single caudal epidural injection, through hiatus sacrus, together a paravertebral injection at both sides of the levels affected by the surgery, followed by 2 sessions of paravertebral procedure one per week.

Retrospective paper from Alexander and cols. described positive results using VAS and Roland Morris Disability Questionaire (RMDQ) in $72 \%$ of FBSS patients treated with paravertebral injections together systemic ozone (SIEVOT). Adding epidurolysis and intradiscal injection increased the good and excellent results up to $78 \%$. Muto in 2008 obtained $60 \%$ of good results with an intradiscal and intraforaminal injection in the same procedure; one month later the patient was evaluated and in case of poor or null result, a second application was done. The results are summarized in table 2.

Table 2

\begin{tabular}{|c|c|c|c|c|c|c|c|c|}
\hline $\begin{array}{l}\text { Author } \\
\text { Year } \\
\text { country }\end{array}$ & Patients & Desing & Quality & Intervention & Outcomes & Timing & Results & Adverse events \\
\hline $\begin{array}{l}\text { Barbosa } \\
2016 \\
\text { Brazil }\end{array}$ & $\begin{array}{c}19 \\
\text { VAS } 8.5 \\
\text { ODI } 37.6 \\
\text { RMDQ } 14.5\end{array}$ & Retrospective & 0 & $\begin{array}{c}\text { Epidurolysis }+ \text { epidural } \\
\text { Ozone } \\
20 \mathrm{~mL} @ 30 \mathrm{mg} / \mathrm{mL} \\
1 \text { session }\end{array}$ & $\begin{array}{l}\text { VAS } \\
\text { ODI } \\
\text { RMDQ } \\
\text { NPSI }\end{array}$ & $\begin{array}{c}3 \\
\text { weeks }\end{array}$ & $\begin{array}{c}\text { VAS improved } 17 \% \\
p<0,01 \\
\text { ODI and RMDQ no } \\
\text { change }\end{array}$ & $? ?$ \\
\hline $\begin{array}{l}\text { Magalhaes } \\
2013 \\
\text { Brazil }\end{array}$ & $\begin{array}{c}13 \\
\text { VAS } 8 \\
\text { ODI } 45\end{array}$ & Prospective & + & $\begin{array}{c}\text { Epidurolysis + epidural } \\
\text { Ozone } \\
20 \mathrm{~mL} @ 30 \mathrm{mg} / \mathrm{mL} \\
1 \text { session }\end{array}$ & $\begin{array}{l}\text { VAS } \\
\text { ODI } \\
\text { DN4 }\end{array}$ & $\begin{array}{c}24 \\
\text { weeks }\end{array}$ & $\begin{array}{l}\text { VAS improved } 70 \% \\
\text { ODI improved } 42 \% \\
p<0,01 \\
\text { Better result for low } \\
\text { back pain }\end{array}$ & $\begin{array}{l}1 \text { headache } \\
1 \text { transient } \\
\text { lower limbs } \\
\text { paraesthesias }\end{array}$ \\
\hline $\begin{array}{l}\text { Hernandez } \\
2013 \\
\text { Mexico }\end{array}$ & $\begin{array}{c}30 \\
\text { VAS } 7.4 \\
\text { ODI } 63.5\end{array}$ & Prospective & + & $\begin{array}{c}\text { Caudal epidural } \\
20 \mathrm{~mL} @ 30 \mathrm{mg} / \mathrm{mL} \\
+ \\
2 \times 20 \mathrm{~mL} @ 30 \mathrm{mg} / \mathrm{mL} \\
\text { paravertebral } \\
1 \text { session } \\
2 \text { more paravertebral } \\
\text { sessions }\end{array}$ & $\begin{array}{l}\text { VAS } \\
\text { ODI }\end{array}$ & $\begin{array}{c}8 \\
\text { weeks }\end{array}$ & No change & $\begin{array}{c}1 \text { headache } \\
12 \text { LBP after } \\
\text { the injection??? }\end{array}$ \\
\hline $\begin{array}{l}\text { Alexandre } \\
2011 \\
\text { Italy }\end{array}$ & $\begin{array}{c}1027 \\
\text { VAS ?? } \\
\text { RMDQ ?? }\end{array}$ & Retrospective & 0 & $\begin{array}{c}\text { Phase 1: } \\
\text { Paravertebral } 10 \mathrm{~mL} @ \\
15 \mathrm{mg} / \mathrm{mL}+\text { SIEVOT } \\
50 \mathrm{~mL} @ 30 \mathrm{mg} / \mathrm{mL} \\
12 \text { sessions + } \\
\text { Phase 2: } \\
\text { Epidurolysis + intradis- } \\
\text { cal 3-20 @ } 35 \mathrm{mg} / \mathrm{mL} \\
1 \text { session }\end{array}$ & $\begin{array}{l}\text { VAS } \\
\text { RMDQ }\end{array}$ & $? ?$ & $\begin{array}{c}\text { Final results } \\
\text { combined VAS and } \\
\text { RMDQ. } \\
\text { Phase } 1 \text { : } \\
72 \% \text { good results. } \\
\text { Phase } 1+2: \\
78 \% \text { good results }\end{array}$ & $\begin{array}{l}2 \text { painful injec- } \\
\text { tions in phase } 1\end{array}$ \\
\hline $\begin{array}{l}\text { Muto } \\
2008 \\
\text { Italy }\end{array}$ & $\begin{array}{c}200 \\
\text { McNab ?? }\end{array}$ & Retrospective & 0 & $\begin{array}{c}\text { Intradiscal } 3 \mathrm{~mL} @ 35 \\
\mathrm{mg} / \mathrm{mL}+\text { intraforaminal } \\
10 \mathrm{~mL} @ 35 \mathrm{mg} / \mathrm{mL} \\
1-2 \text { sessions }\end{array}$ & $\begin{array}{l}\text { Modified } \\
\text { McNab }\end{array}$ & $\begin{array}{c}48 \\
\text { weeks }\end{array}$ & $\begin{array}{c}60 \% \\
\text { good-excellent } \\
\text { results }\end{array}$ & NONE \\
\hline
\end{tabular}




\section{Discussion.}

The epidurolysis followed by ozone insufflation through the epiduroscopic catheter remains controversial after the Barbosa's paper. It is difficult to understand why the got such different results using the same technique with the same surgical team and taking into account that pre-interventional status of the patients were very similar. I encourage the authors to compare both populations in order to clarify this question.

The negative result of Hernandez's publication can be criticized from different point of views. The use of radiological contrast prior to the ozone injection can produce an interaction of both substances not studied previously that could even consume all the ozone injected. In FBSS, the frequent fibrosis can surely block the progression of the gas, avoiding it arriving at the damaged areas. On the other side, the ozone concentrations diminishes dramatically as it leaves the tip of the needle, so long epidural needles $(120-140 \mathrm{~mm})$ should theoretically be much more useful, as they could place useful ozone amounts where they are needed. This is the reason, we think, that intraforaminal (Muto) and epiduroscopic ways of administration produce much better results, as seen in papers from Brazil and Italy.

Interestingly, the use of extra-canal (paravertebral) and systemic (SIEVOT) ozone administration in the paper of Alexander's team yield a significant benefit in $72 \%$ of FBSS patients. This can be easily understood by the association of MPS and FBSS commented in the Introduction section of this paper. Peripheral and central sensitization is usually forgotten by doctors addressing this pathology and should be always checked (only Brazilian team used Neuropathic Pain Symptom Inventory (NPSI) and Douleur Neuropathique 4 (DN4)) and treated if present. This fact will, for sure, improve the results.

We must not forget to look for segmental instability that should be treated as best as possible, as many of these patients are reluctant to more open surgery.

\section{Conclusions.}

From the evidence found, ozone minimally interventional procedures are promising but we are far away to establish a recommendation. At least, prospective comparative studies should be done to whether recommend them or not.

The intradiscal + intraforaminal approach is simple with no side effects found in this revision and can be a good option until epiduroscopic approach clarifies its efficacy.

Phase 1 treatment in Alexander's study, also quite simple and secure, may be the first procedure to do if the patient does not want his spine "touched" again, a very common feeling. 


\section{References}

${ }^{1}$ Merskey NB. Classification of chronic pain: descriptions of chronic pain syndromes and definitions of pain terms prepared by the International Association for the Study of Pain. 2nd ed. Seattle: IASP Press; 1994.

2 Hussain A, Erdek M. Interventional pain management for failed back surgery syndrome. Pain Pract. 2014; 14(1):64-78.

${ }_{3}$ Martin BI, Mirza SK, Comstock BA, Gray DT, Kreuter W, Deyo RA. Are lumbar spine reoperation rates falling with greater use of fusion surgery and new surgical technology? Spine. 2007;32:2119-2126

${ }^{4}$ Ragab A, Deshazo RD. Management of back pain in patients with previous back surgery. Am J Med. 2008; 121(4):272-278.

5 Trescot AM, Chopra P, Abdi S, Datta S, Schultz DM. Systematic review of effectiveness and complications of adhesiolysis in the management of chronic spinal pain: an update. Pain Physician. 2007; 10(1):129-146.

6 Patel VB, Wasserman R, Imani F. Interventional therapies for chronic low back pain: a focused (efficacy and outcomes). Anesthesiol Pain Med. 2015;5(4):e29716.

7 Valverde-Filho J, da Cunha Neto MBC, Fonoff ET, Meirelles ES, Teixeira MJ. Chronic spinal and oral morphine-induced neuroendocrine and metabolic changes in noncancer pain patients. Pain Med. 2015; 16(4):715-725.

8 North RB, Kidd D, Shipley J, Taylor RS. Spinal cord stimulation versus reoperation for failed back surgery syndrome: a cost effectiveness and cost utility analysis based on a randomized, controlled trial. Neurosurgery. 2007;61(2):361-368.

9 Baeza-Noci J, Cabo-Soler JR, Moraleda-Gomez M, Menendez-Cepero S, Re L. WFOT's review on evidence based ozone therapy. World Federation of Ozone Therapy - WFOT. Bolonia: WFOT; 2015. Available from: https://www. wfoot.org/wp-content/uploads/2016/01/WFOT-OZONE-2015-ENG.pdf.

10 Steppan J, Meaders T, Muto M, Murphy KJ. A metaanalysis of the effectiveness and safety of ozone treatments for herniated lumbar discs. Journal of Vascular \& Interventional Radiology. 2010;21(4):534-548.

11 Magalhaes FN, Dotta L, Sasse A, Teixera MJ, Fonoff ET. Ozone therapy as a treatment for low back pain secondary to herniated disc: a systematic review and meta-analysis of randomized controlled trials. Pain Physician. 2012;15(2):E115-129.

12 Muto M, Giurazza F, Silva RP, Guarnieri G. Rational approach, technique and selection criteria treating lumbar disk herniations by oxygen-ozone therapy. Interv Neuroradiol. 2016;22(6):736-740. DOI:10.1177/1591019916659266. ${ }_{13}$ Barbosa DC, Angelos JSD, Macena GMJ, Magalhaes FNO, Fonoff ET. Effects of ozone on the pain and disability in patients with failed back surgery syndrome. Rev Assoc Med Bras (1992). 2017;63(4):355-360. DOI:10.1590/18069282.63.04.355.

14 Donato AD, Fontana C, Pinto R, Beltrutti D, Pinto G. The effectiveness of endoscopic epidurolysis in treatment of degenerative chronic low back pain: a prospective analysis and follow-up at 48 months. Acta Neurochir Suppl. 2011;108:67-73. DOI:10.1007/978-3-211-99370-5_11.

${ }^{15}$ Ghatge S, Modi PD, Modi DB. Clinical and Radiological Improvement Following Ozone Disc Nucleolysis: A Case Report. Cureus. 2017;9(4):e1162. Published 2017 Apr 13. DOI:10.7759/cureus.1162.

16 Magalhaes FN, Soares SC, Torres JM, et al. Effects of ozone applied by spinal endoscopy in patients with chronic pain related to failed back surgery syndrome: a pilot study. Neuropsychiatr Dis Treat. 2013;9:1759-1766. DOI:10.2147/NDT.S48663.

17 Hernandez-Guinea BD, Hernandez-Santos JR, Tenopala-Villegas S, Can- 
seco-Aguilar CP, Torres-Huerta JC. Efficacy of the application of epidural and paravertebral ozone at a concentration of $30 \mu \mathrm{g} / \mathrm{ml}$ for the management of chronic pain in patients with failed back surgery syndrome [Eficacia de la aplicación de ozono epidural y paravertebral a una concentración de $30 \mu \mathrm{g} /$ $\mathrm{ml}$ para el manejo de dolor crónico en pacientes con síndrome de cirugía fallida de espalda]. Rev Soc Esp Dolor [Internet]. 2012 Feb [cited 2020 Nov 09];19(1):3-10. Available from: http://scielo.isciii.es/scielo.php?script=sci_arttext\&pid=S1134-80462012000100002\&Ing=es.

${ }^{18}$ Cánovas L, Castro M. Ozone therapy and fail back surgery syndrome [Ozonoterapia y síndrome de cirugía fallida de espalda]. Rev Soc Esp Dolor [Internet]. 2012 Feb [cited 2020 Nov 09];19(1): 1-2. Available from: http://scielo.isciii. es/scielo.php?script=sci_arttext\&pid=S1134-80462012000100001\&lng=es.

19 Alexandre A, Corò L, Paradiso R, et al. Treatment of symptomatic lumbar spinal degenerative pathologies by means of combined conservative biochemical treatments. Acta Neurochir Suppl. 2011;108:127-135. DOI:10.1007/9783-211-99370-5_20.

20 Muto $\mathrm{M}$, Andreula $\mathrm{C}$, Leonardi $\mathrm{M}$. Treatment of herniated lumbar disc by intradiscal and intraforaminal oxygen-ozone (O2-O3) injection. J Neuroradiol. 2004;31(3):183-189. DOI:10.1016/s0150-9861(04)96989-1.

21 Muto M, Ambrosanio G, Guarnieri G, et al. Low back pain and sciatica: treatment with intradiscal-intraforaminal $\mathrm{O}(2)-\mathrm{O}(3)$ injection. Our experience. Radiol Med. 2008;113(5):695-706. DOI:10.1007/s11547-008-0302-5.

22 Scottish Intercollegiate Guidelines Network (SIGN). Checklists [Internet]. Edinburgh: SIGN; 2020. [cited 2020 Nov 09]. Available from: https://www.sign. ac.uk/what-we-do/methodology/checklists/ 